\title{
Nitrogen fixation by groundnut and velvet bean and residual benefit to a subsequent maize crop
}

\author{
Ambate Okito ${ }^{(1)}$, Bruno José Rodrigues Alves ${ }^{(1)}$, Segundo Urquiaga ${ }^{(1)}$ and Robert Michael Boddey ${ }^{(1)}$
} (1)Embrapa Agrobiologia, Km 47, antiga Rio-São Paulo, CEP 23851-970 Seropédica, RJ, Brazil. E-mail: ambokito@hotmail.com,
bruno@cnpab.embrapa.br, urquiaga@cnpab.embrapa.br, bob@cnpab.embrapa.br

\begin{abstract}
Chemical fertilisers are rarely avaiable to poor farmers, for whom the nitrogen (N) is often the most limiting element for cereal grain production. The objective of this study was to quantify the contribution of biological nitrogen fixation (BNF) to groundnut (Arachis hypogaea) and velvet bean (Mucuna pruriens) crops using the ${ }^{15} \mathrm{~N}$ natural abundance $\left(\delta^{15} \mathrm{~N}\right)$ technique and to determine their residual effect and that of a natural fallow, on growth and $\mathrm{N}$ accumulation by two rustic maize varieties. The contribution of BNF calculated from $\delta^{15} \mathrm{~N}$ data was 40.9, 59.6 and $30.9 \mathrm{~kg} \mathrm{ha}^{-1}$, for groundnut, velvet bean and the natural fallow, respectively. The only legume grain harvested was from the groundnut, which yielded approximately $1.000 \mathrm{~kg} \mathrm{ha}^{-1}$. The subsequent maize varieties ("Sol de Manhã" and "Caiana Sobralha") yielded between 1.958 and $2.971 \mathrm{~kg} \mathrm{ha}^{-1}$, and were higher after velvet bean for both maize varieties and "Sol da Manhã" groundnut, followed by "Caiana" after groundnut and, finally, the natural fallow. For a small-holder producer the most attractive system is the groundnut followed by maize, as, in this treatment, both groundnut and maize grain harvest are possible. However, a simple $\mathrm{N}$ balance calculation indicated that the groundnut-maize sequence would, in the long term, deplete soil $\mathrm{N}$ reserves, while the velvet bean-maize sequence would lead to a build up of soil nitrogen.
\end{abstract}

Index terms: Arachis hypogaea, Mucuna pruriens, Zea mays, ${ }^{15} \mathrm{~N}$ natural abundance technique, green manures, $\mathrm{N}$ balance, small-holder producers.

\section{Fixação de nitrogênio por amendoim e mucuna e benefício residual para uma cultura de milho}

\begin{abstract}
Resumo - Fertilizantes químicos raramente estão disponíveis aos agricultores com poucos recursos econômicos, e assim o $\mathrm{N}$ é, freqüentemente, um elemento mais limitante para a produção de grãos. O objetivo deste trabalho foi quantificar a contribuição da fixação biológica de nitrogênio (FBN) às culturas de amendoim (Arachis hypogaea) e mucuna (Mucuna pruriens), por meio da técnica de abundância natural de ${ }^{15} \mathrm{~N}$ e determinar o efeito residual das leguminosas e do pousio sobre o crescimento e acumulação de $\mathrm{N}$ em duas variedades de milho. A contribuição da FBN calculada a partir dos dados de $\delta^{15} \mathrm{~N}$, foi de 40,9, 59,6 e 30,9 $\mathrm{kg} \mathrm{ha}^{-1}$, respectivamente, para amendoim, mucuna e o pousio. A única leguminosa de grão colhida foi amendoim que produziu aproximadamente $1,000 \mathrm{~kg} \mathrm{ha}^{-1}$. A produtividade da cultura de milho (variedades Caiana e Sol da Manhã) variou de 1,958 a $2,971 \mathrm{~kg} \mathrm{ha}^{-1}$ de grãos, sendo mais alta após mucuna em ambas as variedades de milho e após amendoim na Sol da Manhã, seguida por Caiana após amendoim e por último o pousio normal. Para pequenos agricultores o sistema mais atrativo é o que inclui amendoim seguido pelo milho, uma vez que duas colheitas de grãos são possíveis. Contudo, o cálculo do balanço de $\mathrm{N}$ indicou que a seqüência amendoim-milho diminuiria, a longoprazo, a reserva de $\mathrm{N}$ do solo, enquanto a seqüência mucuna-milho ajudaria a aumentar a reserva de $\mathrm{N}$ do solo.
\end{abstract}

Termos para indexação: Arachis hypogaea, Mucuna pruriens, Zea mays, abundância natural de ${ }^{15} \mathrm{~N}$, adubos verdes, agricultura familiar, balanço de $\mathrm{N}$, rotação de culturas.

\section{Introduction}

High-yielding food-crop varieties and hybrids that were developed for planting in the tropics by International and National Agricultural Research organisations, generally require high inputs of fertilisers and other agrochemicals. In the 1960s and 1970s, when the green revolution began, it was envisaged that these inputs would be available to farmers, both rich and poor, to produce high yields and eliminate hunger in the developing world. Today, while the green revolution technologies have had an immense impact on food production - from 1950 to 1990, world annual grain production tripled, from 631 to 1,780 million metric tonnes -, this technology has failed to reach small- 
holders in many developing countries, even in comparatively wealthy grain exporting countries, such as Brazil and India (Conway, 1997; Urquiaga et al., 1999).

Small-holders often cultivate on sloping land and fragile soils and do not have access to fertilisers. In many developing countries, financial adjustment programs have demanded the removal of fertilizer subsidies, and in some countries this has led to the lowering of grain yields of staple food crops (Keatinge et al., 2001).

Today, research programs planning to increase food production by resource-poor farmers emphasize the minimum but strategic use of chemical fertilizers (Tian et al., 2001; Vanlauwe et al., 2002). There is a heavy emphasis on using legumes for their inputs from biological nitrogen fixation (BNF) either as green manures, intercrops or in agroforestry systems.

Recent reports have shown that in many subsistence crop production systems, soil nutrient mining, especially of soil organic matter, is a common phenomenon (Smaling et al., 1997; Fraga \& Salcedo, 2004). This occurs when export of nutrients in harvested products and from losses through leaching and erosion are greater than the inputs of these same nutrients, and hence soil nutrient reserves become increasingly depleted. As far as nitrogen is concerned, crop rotations including a legume have shown, in many cases, very significant benefits for the yields of accompanying or subsequent non-legume grain crops (Bunch, 1999).

The quantification of the input of biological nitrogen fixation (BNF) to the legumes is an important component of studies to determine whether the $\mathrm{N}$ balance of such cropping systems is positive.

For working on-farm, only two techniques for evaluating BNF inputs are really viable: the ureide abundance technique (Herridge et al., 1988) and the ${ }^{15} \mathrm{~N}$ natural abundance technique (Shearer \& Kohl, 1986). The former relies on the fact that many legumes of tropical origin transport fixed nitrogen from nodules to shoot in the form of ureides (allantoin and allantoic acid), but as this is not true for groundnut, one of the legumes used in this study (Peoples et al., 1989), this technique was not used.

The ${ }^{15} \mathrm{~N}$ natural abundance technique can be applied to quantify BNF to any legume, and has even been applied to $\mathrm{N}_{2}$-fixing non-legumes (Boddey et al., 2001). The use of this technique to quantify BNF inputs to legume crops requires the determination of three parameters: the ${ }^{15} \mathrm{~N}$ natural abundance $\left(\delta^{15} \mathrm{~N}\right)$ of the legume crop at maturity, the $\delta^{15} \mathrm{~N}$ of the $\mathrm{N}$ accumulated by the legume derived from the soil, and, the $\delta^{15} \mathrm{~N}$ of the $\mathrm{N}$ accumulated by the legume derived from the air, i.e. BNF - denominated the $B$ value.

The $\delta^{15} \mathrm{~N}$ of the $\mathrm{N}$ derived from the soil is usually determined on neighbouring non- $\mathrm{N}_{2}$-fixing reference plants, and it is generally recommended that two or more different plant species are used to assess an approximate range of possible values (Boddey et al., 2000; Peoples et al., 2002). The $\delta^{15} \mathrm{~N}$ of the $\mathrm{N}$ derived from BNF is usually determined in greenhouse plants grown in $\mathrm{N}$ free culture, although it is also possible to calculate this value in soil-grown plants if the proportion of that $\mathrm{N}$ (\%Ndfa) by the legumes is simultaneously determined by another method e.g. the ${ }^{15} \mathrm{~N}$ enrichment technique (Doughton et al., 1992; Okito et al., 2004).

The objectives of this study were to quantify the BNF contribution by two tropical legumes, groundnut and velvet bean, using the ${ }^{15} \mathrm{~N}$ natural abundance technique, and to determine their residual effect on growth and $\mathrm{N}$ accumulation by two rustic maize varieties (Machado et al., 2002) with a view to determine whether the quantities of $\mathrm{N}$ exported in the grain (both groundnut and maize) exceeded those put into the system by BNF.

\section{Material and Methods}

\section{Experimental design}

This experiment was conducted at the field station of Embrapa Agrobiologia, Seropédica, RJ, Brazil (224ㄴ S, $43^{\circ} 41^{\prime}$ W). The soil at the site was a Typic Hapludult (Brazilian classification: Argissolo Vermelho-Amarelo distrófico típico) of sandy texture. Granulometric and soil fertility results $(0-15 \mathrm{~cm}$ depth) analyses prior to liming and fertilising are $\mathrm{pH}\left(\mathrm{H}_{2} \mathrm{O}\right), 5.0 ; \mathrm{Al}, \mathrm{Ca}$ and $\mathrm{Mg}$, $0.2,1.7$ and $0.9 \mathrm{cmol}_{\mathrm{c}} \mathrm{dm}^{-3}$, respectively; $\mathrm{P}$ and $\mathrm{K}, 2$ and $36 \mathrm{mg} \mathrm{dm}^{-3}$, respectively; total $\mathrm{N}, 0.11 \mathrm{mg} \mathrm{kg}^{-1}$; sand, silt and clay, 840, 70 and $90 \mathrm{~g} \mathrm{~kg}^{-1}$. The soil was amended with $1,000 \mathrm{~kg} \mathrm{ha}^{-1}$ of dolomitic lime, one week prior to planting.

The two legumes used in this study were velvet bean (Mucuna pruriens (L.) cultivar Utilis) and groundnut (Arachis hypogaea cultivar Tatú). Subsequent to the legume crops, two different maize varieties (Zea mays) were planted, cultivar "Sol de Manhã" and cultivar "Caiana Sobralha".

The experimental design was randomised complete blocks with six treatments and five replicates. The treatments were groundnut followed by maize (cultivar 
"Sol da Manhã", groundnut followed by maize cultivar "Caiana Sobralha", velvet bean followed by maize cultivar "Sol da Manhã," velvet bean followed by maize cultivar "Caiana Sobralha", natural (unweeded) fallowed by maize cultivar "Sol da Manhã" and, natural (unweeded) fallow followed by maize cultivar "Caiana Sobralha".

The plots $(6 \times 6 \mathrm{~m})$ consisted of 11 rows of $6 \mathrm{~m}$ spaced by $60 \mathrm{~cm}$. The two legumes were planted on 19 December, 2001, and the seeds were inoculated with a peat-based inoculant $\left(\sim 10^{9}\right.$ colony forming units $\mathrm{g}$ peat $\left.{ }^{-1}\right)$ of recommended rhizobium strains, for the groundnut, strain BR 423, and for the velvet bean, strain BR 2811, from the collection of $\mathrm{N}_{2}$-fixing bacteria of Embrapa Agrobiologia. In the legume plots weeds were kept under control by hand weeding but in the fallow plots spontaneous vegetation was left undisturbed.

\section{Legume crops harvest}

All aerial tissue of a $20 \mathrm{~m}^{2}$ central area of each plot planted to groundnut was harvested 98 days after planting, the pods were dug out from the soil with minimum possible physical disturbance and all pods taken to estimate total pod yield. Harvested aerial tissue was weighed, chopped in a silage chopper, and approximately $10 \%$ of the material was dried $\left(65^{\circ} \mathrm{C}\right.$ for $>72$ hours $)$, weighed and ground in a Wiley mill $(<0.85 \mathrm{~mm})$ for subsequent analysis. The remaining material was returned to the plots and evenly distributed over the harvested area.

A central area $\left(4 \mathrm{~m}^{2}\right)$ of the velvet bean plots was harvested 124 days after planting and weighed. A subsample of approximately $10 \%$ of the aerial tissue was dried, weighed and ground for subsequent analysis as for the velvet bean material. The remaining material was returned to the plots and evenly distributed over the harvested area.

To serve as non- $\mathrm{N}_{2}$-fixing reference crops for the application of the ${ }^{15} \mathrm{~N}$ natural abundance technique, the whole weed aerial tissue (Digitaria horizontalis,
Sorghum arundinaceum and Cenchrus echinatus) neighbouring the legume plants were collected, dried and ground for subsequent analysis.

All aerial tissue of the spontaneous vegetation from a sub-area of $4 \mathrm{~m}^{2}$ in the centre of each fallow plot was harvested and fresh weight was determined. Subsamples of this material were weighed dried, reweighed and ground for subsequent analysis of $\mathrm{N}$ content as described below.

\section{Analysis}

The ground dried plant samples were submitted in a further grinding process to reducing the material to a fine power using a roller mill similar to that described by Smith and Myung (1990). Aliquots (100 mg) of these samples were analysed for total $\mathrm{N}$ content using the semi-micro Kjeldahl digestion followed by steam distillation using an automated distillation and titration unit, as described by Urquiaga et al. (1992). For samples containing between 35 and $70 \mu \mathrm{g}$ of $\mathrm{N}$ were analysed for ${ }^{15} \mathrm{~N}$ and ${ }^{13} \mathrm{C}$ isotope abundance using a continuousflow isotope-ratio spectrometer consisting of an automatic $\mathrm{C}$ and $\mathrm{N}$ analyser coupled to a mass spectrometer.

\section{Contribution of BNF to the legumes}

To calculate the \%Ndfa of each legume the following equation (Shearer \& Kohl, 1986) was applied:

$\% \mathrm{Ndfa}=100 .\left\{\left(\delta^{15} \mathrm{~N}\right.\right.$ reference plant $-\delta^{15} \mathrm{~N}$ legume $) /$ $\left(\delta^{15} \mathrm{~N}\right.$ reference plant $\left.\left.-B\right)\right\}$.

The values of $B$ of the shoot tissue $\left(B_{s}\right)$, groundnut and velvet bean (-1.41 and $-2.27 \%$, respectively) were taken from the study of Okito et al. (2004) specifically conducted to estimate $B$ values.

\section{Maize crop}

Prior to planting the maize, soil samples were taken again for analysis of fertility parameters (Table 1 ). Spontaneous vegetation, in the fallow plots, was cut with a

Table 1. Dry matter and total $\mathrm{N}$ accumulation of groundnut, velvet bean and spontaneous vegetation in the fallow plots ${ }^{(1)}$.

\begin{tabular}{|c|c|c|c|c|c|c|}
\hline \multirow[t]{2}{*}{ Crop } & \multicolumn{3}{|c|}{ Dry matter $\left(\mathrm{kg} \mathrm{ha}^{-1}\right)$} & \multicolumn{3}{|c|}{ Total $\mathrm{N}$ accumulation $\left(\mathrm{kg} \mathrm{ha}^{-1}\right)$} \\
\hline & Crop-grain $^{(2)}$ & Grain $^{(3)}$ & Whole plant & Crop-grain & Grain $^{(3)}$ & Whole plant \\
\hline Groundnut & $1,648 b$ & $1,002 \pm 23^{(4)}$ & $2,651 \mathrm{a}$ & $32.1 \mathrm{c}$ & $49.4 \pm 1.4^{(4)}$ & $78.0 \mathrm{a}$ \\
\hline Velvet bean & $1,782 b$ & & $1,782 b$ & $84.8 \mathrm{a}$ & & $84.8 \mathrm{a}$ \\
\hline Natural fallow & $2,779 \mathrm{a}$ & & $2,779 \mathrm{a}$ & $49.0 \mathrm{~b}$ & & $49.0 \mathrm{~b}$ \\
\hline $\mathrm{CV}(\%)$ & 16.5 & & 13.9 & 15.7 & & 14.0 \\
\hline
\end{tabular}

${ }^{(1)}$ Means of five replicates in the same column followed by the same letter do not differ significantly at $\mathrm{P}<0.05$ by Student LSD test. ${ }^{(2)}$ Only the grain of groundnut was harvested. ${ }^{3}$ ) Unhulled grain (hulled grain represented $69 \%$ of the dry matter and $91,4 \%$ of the total $\mathrm{N}$ of the unhulled grain). ${ }^{(4)}$ Mean yield \pm standard-error of the mean. 
rotary-blade grass cutter 137 days after planting. Before planting, the plots were fertilized with $\mathrm{P}_{2} \mathrm{O}_{5} 50 \mathrm{~kg} \mathrm{ha}^{-1}$ as single superphosphate, and with $\mathrm{K}_{2} \mathrm{O} 84 \mathrm{~kg} \mathrm{ha}^{-1}$ as potassium chloride. The two varieties of maize were direct drilled with three seeds every $20 \mathrm{~cm}$ in six rows of $6 \mathrm{~m}$ (60 $\mathrm{cm}$ between rows) 140 days after planting. After germination, plants were thinned to one plant every $20 \mathrm{~cm}$.

All maize grains were harvested 270 days after planting in the central four rows from each plot, separated into grain, cob and stover and the fresh weight of each fraction was recorded. The stover and cobs were chopped to facilitate sampling, then sub-samples of each fraction were taken, weighed, dried, weighed again and then ground with a Wiley mill. Total $\mathrm{N}$ content of finely ground aliquots of each fraction was determined as described above for legume plants.

\section{Statistical analysis}

Differences between means were analysed using standard ANOVA procedures by the MSTAT-C software. In each of the five replicate blocks, there were two plots (one for each maize variety) of each green manure treatment (groundnut, velvet bean and natural fallow) and the means of data from each of same green manure plot were pooled for statistical analysis in the experiment first phase.

\section{Results and Discussion}

Considering the whole aerial tissue, the natural fallow and groundnut showed the highest dry matter production (Table 1). This fallow showed abundant growth especially of the legume Indigofera hirsuta. Other species (non-legume) present in the spontaneous vegetation, in the fallow and as weeds in the legume plots were Digitaria horizontalis, Sorghum arundinaceum, Cenchrus echinatus and Cyperus esculentus. Except for Cyperus, these weeds were present in all legume plots and bulked samples were taken from each plot and ground for use as non- $\mathrm{N}_{2^{-}}$ fixing reference plants in order to estimate the BNF contribution to the legumes in the respective plots.

Groundnut dry matter yield was not significantly different to the natural fallow, but significantly higher than that of the velvet bean. However, the much higher concentration of $\mathrm{N}$ in the velvet bean meant that this crop accumulated, approximately, the same $\mathrm{N}\left(84.8 \mathrm{~kg} \mathrm{ha}^{-1}\right)$ as the groundnut, and both accumulated significantly more $\mathrm{N}$ than the natural fallow (Table 1).

The ${ }^{15} \mathrm{~N}$ natural abundance of the three weeds used as reference crops (Digitaria, Sorghum and Cenchrus) were all in the range of +3.2 to $+4.2 \%$, the Cenchrus showing a significantly higher $\delta^{15} \mathrm{~N}$ than the other two (Table 2). The velvet bean showed a negative $\delta^{15} \mathrm{~N}$ value $(-0.82 \%$ ) and the groundnut $+0.96 \%$, which indicated that these legumes obtained considerable contributions from BNF. The negative value of $\delta^{15} \mathrm{~N}$ of the velvet bean indicate that the $B$ value of the shoot tissue was less than $-0.82 \%$, and that probably the $B$ value $(-2.27 \%$ o ) determined for the same velvet bean variety by Okito et al. (2004) was appropriate.

The fallow had a large proportion of the spontaneous legume Indigofera, which was abundantly nodulated, and most other species in the plots were grasses. All legumes possess $\mathrm{C}_{3}$ photosynthetic pathway and exhibit more negative values of ${ }^{13} \mathrm{C}$ than most tropical $\mathrm{C}_{4}$ grasses such as Sorghum, Digitaria and Cenchrus. As the mass spectrometer utilized also provides ${ }^{13} \mathrm{C}$ abundance of the samples, the ${ }^{13} \mathrm{C}$ abundance of the two legumes and the mixture of spontaneous vegetation in the fallow was available. The mean $\delta^{13} \mathrm{C}$ value for groundnut was

Table 2. ${ }^{15} \mathrm{~N}$ natural abundance $\left(\delta^{15} \mathrm{~N}\right)$, proportion of $\mathrm{N}$ derived from BNF (\%Ndfa) and total $\mathrm{N}$ derived from BNF by groundnut, velvet bean and spontaneous vegetation in the fallow plots ${ }^{(1)}$.

\begin{tabular}{|c|c|c|c|c|c|c|}
\hline \multirow{2}{*}{$\begin{array}{l}\text { Crop } \\
\text { legumes }\end{array}$} & \multirow{2}{*}{$\begin{array}{c}\quad \delta^{15} \mathrm{~N}(\% o) \\
\text { Whole shoot }^{(3)}\end{array}$} & \multicolumn{3}{|c|}{$\% \mathrm{Ndfa}^{(2)}$ calculated using } & \multirow{2}{*}{$\begin{array}{l}\text { Mean } \\
\% \text { Ndfa }\end{array}$} & \multirow{2}{*}{$\begin{array}{c}\text { Total } \mathrm{N} \text { derived } \\
\text { from } \mathrm{BNF}\left(\mathrm{kg} \mathrm{ha}^{-1}\right)\end{array}$} \\
\hline & & Digitaria & Sorghum & Cenchrus & & \\
\hline Groundnut & $+0.96 \mathrm{a}$ & 49.0 & 50.2 & 58.0 & 52.4 & $40.9 \mathrm{ab}$ \\
\hline Velvet bean & $-0.82 \mathrm{a}$ & 68.0 & 68.1 & 72.8 & 69.6 & $59.6 \mathrm{a}$ \\
\hline Fallow & $+0.62 b$ & 54.5 & 56.2 & 63.4 & 58.5 & $30.9 \mathrm{~b}$ \\
\hline $\mathrm{CV}(\%)$ & $(0.51)^{(4)}$ & $17.1^{\mathrm{ns}}$ & $13.4^{\mathrm{ns}}$ & $11.6^{\mathrm{ns}}$ & $14.1^{\mathrm{ns}}$ & $18.1^{*}$ \\
\hline
\end{tabular}

${ }^{(1)}$ Means of five replicates in the same column followed by the same letter do not differ significantly at $\mathrm{P}<0.05$ by Student LSD test. (2)The $B$ values used for the calculations of $\% \mathrm{Ndfa}$ were -1.41 and $-2.70 \%$ for the legumes groundnut and velvet bean, respectively. The $B$ value for calculating the $\% \mathrm{Ndfa}$ for the legumes in the fallow (almost solely Indigofera) was $-1.5 \%$. ${ }^{(3)}$ Includes grain and husks of groundnut; $\delta^{15} \mathrm{~N}$ for Digitaria, Sorghum and Cenchrus was $3.24 \mathrm{~b}, 3.35 \mathrm{~b}$ and $4.24 \mathrm{a}$, respectively; coefficient of variation of reference crops was $16.5 \%$. ${ }^{(4)}$ Mean standard error. ${ }^{\text {ns Not- }}$ significant at $\mathrm{P}=0.05$ (F-test). *Significant at $\mathrm{p}=0.05$ (F-test). 
$-28.2 \pm 0.3 \%$ and for the velvet bean, $-28.3 \pm 0.4 \%$. The plant material harvested from fallow plots showed a ${ }^{13} \mathrm{C}$ abundance of $-23.1 \%$.

Assuming that the Indigofera had the same $\delta^{13} \mathrm{C} \%$ o as these two legumes $(-28.25 \%$ o $)$ and that the grasses had a similar $\delta^{13} \mathrm{C}$ to other $\mathrm{C}_{4}$ grasses (e.g. Brachiaria $-11.0 \%$ ) (Cantarutti et al., 2002), if it were further assumed that virtually all the $\mathrm{C}_{3}$ plant material was derived from the Indigofera, and all other plant material was derived from $\mathrm{C}_{4}$ grasses, it would be possible to determine the separate $\mathrm{C}$ proportions that were derived from the legume and the grasses using the simple mixing model of Vitorello et al. (1989), in which the proportion of $\mathrm{C}$ derived from the legume " $\% \mathrm{C}_{\text {leg }}$ " becomes:

$\% \mathrm{C}_{\text {leg }}=100 \times\left(\delta^{13} \mathrm{C}_{\text {Fallow }}-\delta^{13} \mathrm{C}_{\text {grass }}\right) /$

$\left(\delta^{13} C_{\text {Leg }}-\delta^{13} C_{\text {grass }}\right)$

in which $\delta^{13} \mathrm{C}_{\text {Fallow }}$ is the $\delta^{13} \mathrm{C}$ of the plant material harvested from the fallow plots, $\delta^{13} \mathrm{C}_{\text {grass }}$ is the $\delta^{13} \mathrm{C}$ value of the grass $(-11.0 \%$ o $)$ and $\delta^{13} \mathrm{C}_{\mathrm{Leg}}$ that of the legume $(-28.25 \%$ o). This calculation indicated that $70 \%$ of the $\mathrm{C}$ in the plant material harvested from the fallow plots was derived from $\mathrm{C}_{3}$ vegetation, or if it is assumed that the $\% \mathrm{C}$ in the dry matter of all species was the same, approximately $70 \%$ of the dry matter $\left(1,950 \mathrm{~kg} \mathrm{ha}^{-1}\right)$ harvested from the fallow plots was Indigofera.

The ${ }^{15} \mathrm{~N}$ abundance of the reference crop Cenchrus was significantly higher, approximately $1 \delta^{15} \mathrm{~N}$ unit, than the other two reference plants (Table 2). However, when the proportion on $\mathrm{N}$ derived from $\mathrm{BNF}$ (\% Ndfa) of the legumes is high, the estimates of $\% \mathrm{Ndfa}$ are less sensitive to differences in ${ }^{15} \mathrm{~N}$ abundance of crops (Hardarson et al., 1988; Boddey et al., 1995). Therefore the three estimates of $\% \mathrm{Ndfa}$ derived from the three different reference plants were similar, ranging from $49 \%$ to $58 \%$ to groundnut, $68 \%$ to $73 \%$ to velvet bean and $54 \%$ to $63 \%$ for the legume component of the spontaneous fallow (Table 2).

For subsequent calculations, the mean values of the $\%$ Ndfa were used, and indicated that groundnut and velvet bean accumulated 40.9 and $59.6 \mathrm{~kg} \mathrm{~N}^{-1}$ from BNF, respectively, and the Indigofera $30.9 \mathrm{~kg} \mathrm{~N}^{-1}$ (Table 2). Previous studies to quantify the BNF contribution to groundnut in Thailand used higher fertility soils and added more $\mathrm{P}$ and $\mathrm{K}$ fertilizer, and yields were higher than in this study from 1,700 to 2,800 kg grain ha ${ }^{-1}$ (Suwanarit et al., 1986; McDonagh et al., 1993). However, the proportion of $\mathrm{N}$ derived from $\mathrm{BNF}$ in these studies ranged from $53 \%$ to $67 \%$, slightly higher than in this study and in a previous study at two sites in Brazil (Embrapa Agrobiologia, Seropédica, RJ, and Embrapa Cerrados, Planaltina, DF) using the ${ }^{15} \mathrm{~N}$ enrichment technique (Boddey et al., 1990).

The highest grain yields of the maize were registered by the "Sol de Manhã" and "Caiana Sobralha" varieties direct drilled into the residues of velvet bean and "Sol da Manhã" following groundnut (Table 3). The former maize variety (Sol da Manhã) yielded 2,971 kg ha-1 after velvet bean and $2,574 \mathrm{~kg} \mathrm{ha}^{-1}$ following the groundnut and $1,958 \mathrm{~kg} \mathrm{ha}^{-1}$ following the fallow. Yields of "Caiana Sobralha" were slightly lower, scoring 2,634, 2,153 and $2,160 \mathrm{~kg} \mathrm{ha}^{-1}$ after velvet bean, groundnut and fallow, respectively.

Maize crops, all shoot tissue, accumulated $\mathrm{N}$ between 51 and $74.5 \mathrm{~kg} \mathrm{ha}^{-1}$, but assuming all stover and cobs were left in the field, direct export of $\mathrm{N}$ in the grain amounted between 32 and $52 \mathrm{~kg} \mathrm{ha}^{-1}$, and was highest

Table 3. Dry matter and total N accumulation of maize varieties "Caiana Sobralha" and "Sol da Manhã" planted after groundnut, velvet bean or natural fallow grown in an low fertility Typic Hapludult ${ }^{(1)}$.

\begin{tabular}{|c|c|c|c|c|c|c|}
\hline \multirow{3}{*}{$\begin{array}{l}\text { Legume crop } \\
\text { before maize }\end{array}$} & \multicolumn{3}{|c|}{ Dry matter } & \multicolumn{3}{|c|}{ Total $\mathrm{N}$ accumulation } \\
\hline & Stover ${ }^{(2)}$ & Grain & Whole plant & Stover ${ }^{(2)}$ & Grain & Whole plant \\
\hline & ------------ & $-\left(\mathrm{kg} \mathrm{ha}^{-1}\right)$ & ------------------ & \multicolumn{3}{|c|}{ 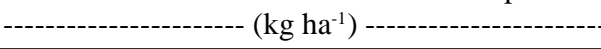 } \\
\hline & \multicolumn{6}{|c|}{ "Caiana Sobralha" } \\
\hline Groundnut & $3,233 \mathrm{bc}$ & $2,153 \mathrm{bc}$ & $5,386 \mathrm{bc}$ & $16.5 b$ & $34.1 \mathrm{bc}$ & $50.6 \mathrm{bc}$ \\
\hline Velvet bean & $3,907 \mathrm{a}$ & $2,634 \mathrm{ab}$ & $6,541 \mathrm{a}$ & $19.8 \mathrm{ab}$ & $42.6 \mathrm{ab}$ & $62.4 \mathrm{ab}$ \\
\hline \multirow[t]{2}{*}{ Fallow } & $3,098 \mathrm{bc}$ & $2,160 \mathrm{bc}$ & $5,258 \mathrm{bc}$ & $15.9 \mathrm{~b}$ & $32.2 \mathrm{c}$ & $48.2 \mathrm{c}$ \\
\hline & \multicolumn{6}{|c|}{ "Sol da Manhã" } \\
\hline Groundnut & $3,490 \mathrm{ab}$ & $2,574 \mathrm{ab}$ & $6,063 \mathrm{ab}$ & $18.1 \mathrm{ab}$ & $42.7 \mathrm{ab}$ & $60.8 b c$ \\
\hline Velvet bean & $3,947 \mathrm{a}$ & $2,971 \mathrm{a}$ & $6,918 \mathrm{a}$ & $22.7 \mathrm{a}$ & $51.8 \mathrm{a}$ & $74.5 \mathrm{a}$ \\
\hline Fallow & $2,837 \mathrm{c}$ & $1,958 \mathrm{c}$ & $4,795 \mathrm{c}$ & $16.7 \mathrm{~b}$ & $33.6 \mathrm{bc}$ & $50.3 b c$ \\
\hline $\mathrm{CV}(\%)$ & 13.6 & 16.5 & 14.0 & 20.1 & 18.8 & 17.5 \\
\hline
\end{tabular}

${ }^{(1)}$ Means of five replications in the same column followed by the same letter do not differ significantly at $\mathrm{P}<0.05$ by Student LSD test. ${ }^{(2)}$ Stover includes stem leaves and cobs after removing the grain. 
for "Sol da Manhã" following velvet bean (51.8 $\left.\mathrm{kg} \mathrm{ha}^{-1}\right)$ and lowest for "Caiana Sobralha" following the natural fallow $\left(32.2 \mathrm{~kg} \mathrm{ha}^{-1}\right)$.

Field conditions under which this study was conducted were somewhat unusual in that the spontaneous vegetation in the fallow contained a very high proportion $(\sim 70 \%)$ of the legume Indigofera hirsuta. Even without planting a leguminous green manure crop, the contribution of BNF of this fallow approximated $31 \mathrm{~kg} \mathrm{ha}^{-1}$, over half that accumulated by the velvet bean. Under these specific conditions, a farmer might decide that, in order to save the cost of labour and seed, the best option would be to use it as natural fallow. However, at this site experience has shown that I. hirsuta does not usually persist if the fallow area cropped for a few years.

The highest maize yields were obtained after velvet bean (Table 3), and this legume accumulated and fixed most N. However, while the maize grain yields following groundnut were on average $440 \mathrm{~kg} \mathrm{ha}^{-1}$ lower, the option to use groundnut is more favourable to the farmer as, on the other hand, $1,000 \mathrm{~kg}$ of groundnut grain was also harvested (Table 1). Maize and groundnut farmer prices in March 2004 were R\$ 0.28 and $\mathrm{R} \$ 0.84$ per $\mathrm{kg}$, respectively, (US\$ $1.00 \cong \mathrm{R} \$ 3.00$ ) such that overall income per ha was $\mathrm{R} \$ 777$ to the maize after velvet bean, and $\mathrm{R} \$ 662$ for the maize after groundnut, but the $\left(1,002 \mathrm{~kg} \mathrm{ha}^{-1}\right)$ groundnut gave an additional income of $\mathrm{R} \$ 842$. Not only would the farmer increase his gross annual income per ha by $\mathrm{R} \$ 727$, but he would also have an income from field twice a year.

The $\mathrm{N}$ balances displayed in Table 4, are oversimplified and do not take into account $\mathrm{N}$ many inputs and losses from the green manure - maize sequence. Recent studies on grain and forage legumes in Australia have shown that overall BNF inputs to legumes are considerably underestimated, if below-ground $\mathrm{N}$ is not

Table 4. Simple N balance for the sequence of groundnut, velvet bean or natural fallow followed by maize varieties "Sol da Manhã" and "Caiana Sobralha".

\begin{tabular}{|c|c|c|c|c|}
\hline $\begin{array}{l}\text { Legume crop } \\
\text { before maize }\end{array}$ & $\begin{array}{l}\mathrm{N} \text { derived } \\
\text { from } \mathrm{BNF}\end{array}$ & $\begin{array}{l}\mathrm{N} \text { exported in } \\
\text { legume grain }\end{array}$ & $\begin{array}{c}\mathrm{N} \text { exported } \\
\text { in maize grain }\end{array}$ & $\begin{array}{r}\text { Overall N } \\
\text { balance }^{(1)}\end{array}$ \\
\hline \multicolumn{5}{|c|}{ - } \\
\hline \multicolumn{5}{|c|}{ "Caiana Sobralha" } \\
\hline Groundnut & 55.6 & 49.4 & 34.1 & -27.9 \\
\hline Velvet bean & 59.6 & 0.0 & 42.6 & +17.0 \\
\hline Fallow & 30.9 & 0.0 & 32.2 & -1.3 \\
\hline \multicolumn{5}{|c|}{ "Sol da Manhã" } \\
\hline Groundnut & 55.6 & 49.4 & 42.7 & -36.5 \\
\hline Velvet bean & 59.6 & 0.0 & 51.8 & +7.8 \\
\hline Fallow & 30.9 & 0.0 & 33.6 & -2.7 \\
\hline
\end{tabular}

${ }^{(1)} \mathrm{N}$ balance calculated from export of $\mathrm{N}$ in grains minus input of $\mathrm{N}$ from BNF in aerial tissue. taken into account (McNeill et al., 1997; Khan et al., 2003). These authors not only manually recovered legume roots, but also computed $\mathrm{N}$ lost from the roots to the soil by using a ${ }^{15} \mathrm{~N}$ leaf- or stem-labelling technique. These studies suggested that, at least $30 \%$ of all $\mathrm{N}$ plant at harvest was to be found below ground, and in this study it would mean that the $\mathrm{N}$ balances would be between 10 and $15 \mathrm{~kg} \mathrm{ha}^{-1}$ more positive. On the other hand no measure of $\mathrm{N}$ losses via leaching, denitrification or ammonia volatilization were estimated, such that the balances would be less positive than those displayed in Table 4.

Therefore, data suggest that the long-term use of the sequence of the legume followed by maize would, in the case of velvet bean - maize, lead to an increase in soil $\mathrm{N}$ (and hence organic matter) with time (Table 4). In the case of the fallow, the balance was approximately zero, suggesting that if the below-ground contribution were, approximately, balanced by the gaseous and leaching losses of $\mathrm{N}$, this system would maintain soil $\mathrm{N}$ reserves. However that is unlikely to occur on the groundnut-maize sequence. This system is probably most attractive to the farmer, in which both groundnut and maize grain can be harvested, but the long-term use of this sequence is likely to lead to a large depletion of soil $\mathrm{N}$ reserves.

The study showed the viability of the application of the ${ }^{15} \mathrm{~N}$ natural abundance technique to quantify the BNF contributions to a legume - cereal crop sequence. The results also emphasize the need for on-farm studies of a similar nature, in which below-ground BNF contributions and $\mathrm{N}$ losses are also quantified to asses the long-term sustainability of such cropping systems.

\section{Conclusions}

1. Velvet bean and groundnut can benefit from significant amounts of $\mathrm{N}$ derived from $\mathrm{BNF}$, and both are capable of increasing the yield of a subsequent maize crop in low fertility soils.

2 . The velvet bean use as green manure favours higher maize yields and results in a more positive soil $\mathrm{N}$ balance since all fixed $\mathrm{N}$ is kept in the field as plant biomass.

3. Greater profitability is achieved with the double cash-crop sequence groundnut-maize, but it can be shortlived in view of soil deterioration caused by the negative soil $\mathrm{N}$ balance. 


\section{References}

BODDEY, R.M.; OLIVEIRA, O.C. de; ALVES, B.J.R.; URQUIAGA, S. Field application of the ${ }^{15} \mathrm{~N}$ isotope dilution technique for the reliable quantification of plant-associated biological nitrogen fixation. Fertilizer Research, v.42, p.77-87, 1995.

BODDEY, R.M.; PEOPLES, M.B.; PALMER, B.; DART, P.J. Use of the ${ }^{15} \mathrm{~N}$ natural abundance technique to quantify biological nitrogen fixation by woody perennials. Nutrient Cycling in Agroecosystems, v.57, p.235-270, 2000.

BODDEY, R.M.; POLIDORO, J.C.; RESENDE, A.S.; ALVES, B.J.R.; URQUIAGA, S. Use of the ${ }^{15} \mathrm{~N}$ natural abundance technique for the quantifiation of the contribution of $\mathrm{N}_{2}$ fixation to sugar cane and other grasses. Australian Journal of Plant Physiology, v.28, p.889-895, 2001.

BODDEY, R.M.; URQUIAGA, S.; SUHET, A.R.; PERES, J.R.; NEVES, M.C.P. Quantification of the contribution of $\mathrm{N}_{2}$ fixation to field-grown legumes: a strategy for the practical application of the ${ }^{15} \mathrm{~N}$ isotope dilution technique. Soil Biology and Biochemistry, v.22, p.649-655, 1990.

BUNCH, R. More productivity with fewer external inputs: Central American case studies of agroecological development and their broader implications. Environment, Development and Sustainability, v.1, p.219-233, 1999.

CANTARUTTI, R.B.; TARRÉ, R.; MACEDO, R.; CADISCH, G.; REZENDE, C. de P.; PEREIRA, J.M.; BRAGA, J.M.; GOMIDE, J.A.; FERREIRA, E.; ALVES, B.J.R.; URQUIAGA, S.; BODDEY, R.M. The effect of grazing intensity and the presence of a forage legume on nitrogen dynamics in Brachiaria pastures in the Atlantic forest region of the South of Bahia, Brazil. Nutrient Cycling in Agroecosystems, v.64, p.257-271, 2002.

CONWAY, G. The doubly green revolution: food for all in the 21st century. London: Penguin Books, 1997. 336p.

DOUGHTON, J.A.; VALLIS, I.; SAFFIGNA, P.G. An indirect method for estimating ${ }^{15} \mathrm{~N}$ isotope fractionation during nitrogen fixation by a legume under field conditions. Plant and Soil, v.144, p.23-29, 1992.

FRAGA, V. da S.; SALCEDO, I.H. Declines of organic nutrient pools in tropical semi-arid soils under subsistence farming. Soil Science Society of America Journal, v.68, p.215-224, 2004.

HARDARSON, G.; DANSO, S.K.A.; ZAPATA, F. Dinitrogen fixation measurements in alfalfa-ryegrass swards using nitrogen-15 and the influence of the reference crop. Crop Science, v.28, p.101105, 1988.

HERRIDGE, D.F.; O'CONNELL, P.; DONNELLY, K. The xylem ureide assay of nitrogen fixation: Sampling procedures and sources of error. Journal of Experimental Botany, v.39, p.12-22, 1988.

KEATINGE, J.D.H.; BREMAN, H.; MANYONG, V.M.; VANLAUWE, B.; WENDT, J. Sustaining soil fertility in West Africa in the face of rapidly increasing pressure for agricultural intensi- fication. In: TIAN, G.; ISHIDA, F.; KEATINGE, D. (Ed.). Sustaining soil fertility in West Africa. Madison, WI: Soil Science Society of America; American Society of Agronomy, 2001. p.1-22. (Special Publication, 58).

KHAN, D.F.; PEOPLES, M.B.; SCHWENKE, G.D.; FELTON, W.L.; CHEN, D.; HERRIDGE, D.F. Effects of below-ground nitrogen on $\mathrm{N}$ balances of field-grown fababean, chickpea and barley. Australian Journal of Agricultural Research, v.54, p.333-340, 2003.

MACHADO, A.T.; MACHADO, C.T. de T.; COELHO, C.H.M.; ARCANJO, J.N. Manejo da diversidade genética do milho e melhoramento participativo em comunidades agrícolas nos estados do Rio de Janeiro e Espírito Santo. Planaltina: Embrapa Cerrados, 2002. 22p. (Embrapa Cerrados. Boletim de Pesquisa e Desenvolvimento, 32).

MCDONAGH, J.F.; TOOMSAN, B.; LIMPINUNTANA, V.; GILLER, K.E. Estimates of the residual nitrogen benefit of groundnut to maize in Northeast Thailand. Plant and Soil, v.154, p.267-277, 1993.

MCNEILL, A.M.; ZHU, C.; FILLERY, I.R.P. Use of in situ ${ }^{15} \mathrm{~N}-$ labelling to estimate the total below-ground nitrogen of pasture legumes in intact soil-plant systems. Australian Journal of Agricultural Research, v.48, p.295-304, 1997.

OKITO, A.; ALVES, B.J.R.; URQUIAGA, S.; BODDEY R.M. Isotopic fractionation during $\mathrm{N}_{2}$ fixation by four tropical legumes. Soil Biology and Biochemistry, v.36, p.1179-1190, 2004.

PEOPLES, M.B.; BODDEY, R.M.; HERRIDGE, D.F. Quantification of nitrogen fixation. In: LEIGH, G.J. (Ed.). Nitrogen fixation at the millenium. Brighton: Elsevier, 2002. p.357-389.

PEOPLES, M.B.; FAIZAH, A.W.; RERKASEM, B.; HERRIDGE, D.F. Methods for evaluating nitrogen fixation by nodulated legumes in the field. Canberra: ACIAR, 1989. 76p. (Monograph, 11).

SHEARER, G.B.; KOHL, D.H. $\mathrm{N}_{2}$-fixation in field settings: estimations based on natural ${ }^{15} \mathrm{~N}$ abundance. Australian Journal of Plant Physiology, v.13, p.699-756, 1986.

SMALING, E.M.A.; NANDWA, S.M.; JANSSEN, B.H. Soil fertility in Africa is at stake. In: BURESH, R.J.; SANCHEZ, P.A.; CALHOUN, F. (Ed.). Replenishing soil fertility in Africa. Madison, WI: Soil Science Society of America, 1997.p.47-62. (Special Publication, 51).

SMITH, J.L.; MYUNG, H.U. Rapid procedures for preparing soil and $\mathrm{KCl}$ extracts for ${ }^{15} \mathrm{~N}$ analysis. Communications in Soil Science and Plant Analysis, v.21, p.2173-2179, 1990.

SUWANARIT, A.; SUWANNARAT, C.; CHOTECHAUNGMANIRAT, S. Quantities of fixed $\mathrm{N}$ and effects of grain legumes on following maize, and $\mathrm{N}$ and $\mathrm{P}$ status of soil as indicated by isotopes. Plant and Soil, v.93, p.249-258, 1986. 
TIAN, G.; HAUSER, S.; KOUTIKA, L.-S.; ISHIDA, F.; CHIANU, J.N. Pueraria cover crop fallow systems: Benefits and applicability. In: TIAN, G.; ISHIDA, F.; KEATINGE, D. (Ed.). Sustaining soil fertility in West Africa. Madison,WI: Soil Science Society of America; American Society of Agronomy, 2001. p.137-155.

URQUIAGA, S.; BODDEY, R.M.; NEVES, M.C.P. A necessidade de uma revolução mais verde. In: SIQUEIRA, J.O.; MOREIRA, F.M.S.; LOPES, A.S.; GUILHERME, L.R.G.; FAQUIN, V.; FURTINI NETO, A.E.; CARVALHO, J.G. (Ed.). Inter-relação fertilidade, biologia do solo e nutrição de plantas. Lavras: SBCS, 1999. p.175-181.
URQUIAGA, S.; CRUZ, K.H.S.; BODDEY, R.M. Contribution of nitrogen fixation to sugar cane: Nitrogen-15 and nitrogen-balance estimates. Soil Science Society of America Journal, v.56, p.105114, 1992.

VANLAUWE, B.; DIELS, J.; SANGINGA, N.; MERCKX, R. Integrated plant nutrient management in Sub-Saharan Africa: from concept to practice. Wallingford, Oxon: CABI Publications, 2002. 352p.

VITORELLO, V.A.; CERRI, C.C.; ANDREUX, F.; FELLER, C.; VICTORIA, R.L. Organic matter and natural carbon-13 distribution in forested and cultivated oxisols. Soil Science Society of America Journal, v.53, p.773-778, 1989.

Received on Abril 16, 2004 and accepted on September 3, 2004 